The Studia Philonica Annual 19 (2007) 0-00

\title{
DIVINE SONSHIP AT QUMRAN AND IN PHILO
}

\author{
FLORENTINO GARCÍA MARTÍNEZ
}

I have recently completed a study of the concept of divine sonship at Qumran in which I looked at the three categories in which texts that speak of divine sonship in the Hebrew Bible are commonly grouped: 1) the angelic "sons of God"; 2) Israel, "son of God"; 3) the king, "son of God." I wished to show, with the help of some selected texts, the progress (or the modifications) that we can register in the Dead Sea Scrolls in each one of these categories with respect to the idea of divine sonship. ${ }^{1}$ To these three classical categories I have added a fourth that is not found in the Hebrew Bible, but which appears in some Qumranic texts: 4) the Messiah, "son of God."

In this short presentation I will give a summary of the conclusions of this study, and then proceed to compare these conclusion with some aspects of the idea of divine sonship I have found in the writings of Philo of Alexandria. The point of the exercise, as I understood it, was to look at the materials from Philo with the eyes of somebody trained in another field and used to reading other texts. First, then, the conclusions of the study of the Qumran texts.

\footnotetext{
* This paper was presented at the meeting of the Philo seminar in Philadelphia and intends to start conversations across disciplines. I thank Hindy Najman for her kind invitation to participate in the discussion.

1 Now published as "Divine Sonship at Qumran: Between the Old and the New Testament," in Biblical Traditions in Transmission. Essays in Honour of Michael A. Knibb (eds Charlotte Hempel and Judith M. Lieu; JSJS 111; Leiden: Brill, 2006), 109-132. This study has been reprinted in Qumranica minora II: Thematic Studies on the Dead Sea Scrolls (STDJ 64; Leiden: Brill, 2007), 261-283.
} 


\section{Divine Sonship at Qumran}

(1) The angelic "sons of God"

The expression "sons of (the) God(s)" (בני [ה]אלהים), name to designate angelic beings in Gen 6:2,4 and Job 1:6, 2:1, and 28:73 is not used at Qumran, where it is usually replaced by "sons of heavens" (בני שמים), both in the Hebrew texts" and in the texts in Aramaic. ${ }^{5}$

In the Hebrew Bible, the divine sonship of the angels represents either an echo of the original plurality of divine beings, an adaptation of the Canaanite divine council, or the remains of an already surpassed mythology. ${ }^{6}$ It was used more as a taxonomic element intended to underline its appurtenance to the celestial order and its distinction from the realm of humans than to indicate a father-son relationship. The occasional and very restricted survival of this terminology within the angelology of Qumran seems to have the same function. This appears most clearly when considering one of the most frequently used generic names for the angels: אלים (divine beings). The name appears more than 50 times (20 in the Songs of the Sabbath Sacrifice). ${ }^{7}$ The name אלים underlines the heavenly nature of the angels, leaving aside the theme of divine sonship. The same happens with the use of other divine names that are used of angels, including אלוהים

At Qumran, the angels are not "sons of God," but their heavenly nature is strongly underlined. ${ }^{8}$ On this point, the texts from Qumran are no

2 There is abundant literature on the topic. Among the classic studies, see Werner Schlisske, Gottessöhne und Gottessohn im Alten Testament. Phasen der Entmythisierung im Alten Testament (Beiträge zur Wissenschaft von Alten und Neuen Testament; Stuttgart: Kohlhammer, 1973). Among the more recent studies, see Mark S. Smith, The Early History of God. Yahweh and the Other Deities in Ancient Israel (San Francisco: Harper \& Row, 1990).

3 And originally in Deut 32:8, as proved by a copy of Deut from Cave 4 (4Q37, 4QDeut') which uses it (as the LXX) where MT has changed it to "sons of Israel." See Eugene Ulrich et al., Qumran Cave 4.IX: Deuteronomy, Joshua, Judges, Kings (DJD 14; Oxford: Clarendon, 1995), 90.

4 See 1QS 4:22; 11:8; 1QH 11:2; 2 i 10; 4Q181 1:2; 4Q416 1,12; 4Q418 2+2ca-c, 4; 69 ii 12.

5 See 1Q20 2:5; 2:16; 5:3; 6:8; 4Q546 14,4.

6 See E.T. Mullen, The Assembly of the Gods. The Divine Council in Cannanite and Early Hebrew Literature (Harvard Semitic Monographs 24; Chico: Scholars Press, 1980).

7 See Carol A. Newsom, Songs of the Sabbath Sacrifice. A Critical Edtion (Harvard Semitic Studies 27; Atlanta: Scholars Press, 1985), $23-29$.

8 On Qumranic angelology see Maxwell J. Davidson, Angels at Qumran (JSPSS 11; Sheffield: Sheffield Academic Press, 1992). 
different from the rest of the Jewish literature of the time and show the same general development of the angelology of the period. ${ }^{9}$

Other aspects of Qumran angelology, however, show us a clear development because they extend angelic characteristics to humans. This is the case, for example, of Noah who was "not like a man, but like the children of the angels of heaven,"10 or of Moses, "who spoke like an angel with his mouth" (וכמלאך ידבר מפיהו) as it is said in 4Q377 1 ii 11,11 or whom God "made him like a God" (שיתנו לאלוהים), as it is asserted in 4Q374 2 ii 6.12 At Qumran, a human person (an exceptional one, of course) can be equal to angelic beings, "the sons of God." And the same thing happens with the members of the group, the "sons of light," who are somehow equated with the angels.

The communion between angels and men is expressed in the texts as "sharing the lot" (גורל), a term that appears more than 100 times in the preserved texts and that reveals the ultimate origin of this belief: the dualistic thinking of the group in which humanity is divided into two camps: "sons of light" and "sons of darkness."13 In the eschatological war both "lots" are associated with the angelic host, ${ }^{14}$ which is intended to endure forever, ${ }^{15}$ and fight one against the other. ${ }^{16}$ The language of election and inheritance used in these texts and the references to communal structures show us that this communion with the angelic world is the exclusive privilege of the members of the community who partake of the heavenly

9 See Gerhard Delling, “Die Bezeichnung 'Söhne Gottes' in der jüdischen Literatur der hellenistisch-römischen Zeit," God's Christ and His People (eds. Jacob Jervell and Wayne A. Meeks; Oslo: Universitetsforlaget i Aarhus, 1977), 18-281 and Brendan Byrne, "Sonship of God in the Intertestamental Literature," in "Sons of God" - "Seed of Abraham." A Study of the Idea of the Sonship of God of All Christians in Paul against the Jewish Background (Analecta Biblica 83; Rome: Pontificio Istituto Biblico 1979), 18-70. The most complete overview is given by M. Mach, Entwicklugnstadien des jüdischen Engelglaubens in vorrabbinischer Zeit (Tübingen: Mohr Siebeck, 1992).

10 As it is said in 1 Enoch 106:5 and confirmed in 1QapGen 2:1.

11 The text has been published by James C. VanderKam and Monica Brady in Moshe Bernstein et al., Qumran Cave 4. XXVIII: Miscellanea, Part 2 (DJD 28; Oxford: Clarendon, 2001), 205-217; 213.

12 The text has been published by Carol A. Newsom in Magen Broshi et al., Qumran Cave 4. XIX: Parabiblical Texts 2 (DJD 19; Oxford: Clarendon, 1995), 99-110; 102.

13 See 1QS 3:13 - 4:26.

14 The association of the impious with the host of evil angels is even expressed with the terminology of "sonship," since the expression בליעל בני "sons of Belial" is found five times: 4Q174 1:8; 4Q286 7 ii 6; 4Q386 1 ii 3; 4Q525 25,2 y 11Q11 6:3.

15 See 1QS 11:7-8.

16 See 1QM 1:10-11. 
cult, fight together the eschatological battle, and use angelic language to express their community with the angelic "sons of God."

\section{(2) Israel, "son of God"}

The idea that a clan, a tribe or an entire people has a special relationship with its own god is something common in the Semitic world. This idea is frequently expressed with the metaphor of sonship, which does not intend to express any genetic relationship. ${ }^{17}$ The themes which express this special relationship of God with the people of Israel in terms of sonship are many, and all of them underline its metaphorical character: the father-creator, ${ }^{18}$ the father-corrector, ${ }^{19}$ the father-helper in danger, ${ }^{20}$ and the father full of tenderness ${ }^{21}$ are the most frequent. The motifs are formulated in terms of election, covenant and the promise of inheritance (of the land of Israel). Exod 4:22 expresses the same motif in terms of primogeniture: "Israel is my first-born son," and Jer 31:9 announces the renewal of this relationship in terms of the new covenant: "For I am ever a father to Israel, Ephraim is my first-born." Even in the most solemn and strong expression of the divine sonship of Israel in Deut 14:1 ("You are the children of YHWH your God," (בנים אתם ליהוה אלהיכם does not imply any genetic relationship but expresses rather the peculiar relationship of Israel with God in the context of election and the covenant: "For you are a people consecrated to YHWH your God: YHWH your God chose you (בחר) to be his treasured people from among all other peoples on earth."

The use of this metaphor continues, of course, in the Dead Sea Scrolls. In one of the prayers from the composition known as Words of the Luminaries (a prayer intended to be recited on Thursday) we read:

Behold, all the peoples are like nothing in front of you; they are reckoned as chaos and nothing in your presence. We have invoked only your name; for your glory you have created us; you have established us as your sons in the

17 The "canticle of Moses" in Deut 32 is a good example, with a significant concentration of the uses of the metaphor.

18 For example, Isa 64:7: "But now, YHWH, You are our father; we are the clay, and You are the potter. We are all the work of your hands."

19 For example, Deut 8:5: "Bear in mind that $\mathrm{YHWH}$ your God disciplines you just as a man disciplines his son."

${ }^{20}$ For example, Wisdom 2:18: "For if the just one be the son of God, he will defend him and deliver him from the hand of his foes."

${ }^{21}$ For example, Hos 11:1: "I fell in love with Israel, when he was still a child; and I have called (him) my son ever since Egypt." 
sight of all the peoples. For you called Israel "my son, my first born" and have corrected us as one corrects a son. (4Q504 1-2 iii 3-7) ${ }^{22}$

Besides this reproduction of the data of the Hebrew Bible, I think that at Qumran we can ascertain two lines of development of the idea of the divine sonship of Israel. On the one hand, we can observe the use of the metaphor at an individual level to express the inner relationship with God not of Israel as such, but of a single person. On the other hand, the extension of the divine sonship of Israel tends to be restricted to the members of the group only.

A good example of the first line of development is found in the Apocryphon of Joseph (4Q372) ${ }^{23}$ where the protagonist appeals directly to the theme of sonship:

And he said: "My father and my God (אבי ואלהי), do not abandon me into the hands of gentiles, do me justice, so that the poor and afflicted do not die . . And your tenderness is great and great is your compassion for all who seek you; they are stronger than me and all my brothers who are associated with me." (4Q372 1:16-20)

The protagonist, the eponymous ancestor of the tribes of the North, presents himself in an anguishing situation, in exile, surrounded by enemies, and having recourse to God as saviour, appealing directly to the theme of "sonship." The narrative context of the composition as a whole makes clear that the Patriarch represents the people and contains a clear polemic against the Samaritans and their pretension to being the true descendants of the Patriarch. The true descendants of Joseph are, however, in a situation of exile, and in this situation each one of them may call upon God for salvation as Joseph did. This prayer, calling God "my father," has preserved the oldest attestation of the expression by a person other than David. ${ }^{24}$

Another text in which the same expression appears is $4 \mathrm{Q} 460$, where we can read at the end of a section: "[. . .] for you have not abandoned your servant (לעבדכה) [. . . my Father and my Lord (אבי ואדוני)" The "servant"

22 Published by Maurice Baillet, Qumrân Grotte 4. III (DJD 7; Oxford: Clarendon, 1982), 137-177, translation by Florentino García Martínez, The Dead Sea Scrolls Translated, 414.

23 Published now by Eileen M. Schuller in Moshe Bernstein et al., Qumran Cave 4. XXVIII(DJD 28; Oxford: Clarendon, 2001), 165-197, as 4QNarrative and Poetic Composition.

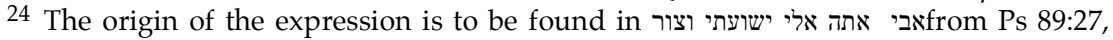
which put it in the mouth of David, and corresponds to the use of "father" in the Nathan oracle, 2 Sam 7:14. On the position of this composition within the context of Second Temple prayers, see Eileen M. Schuller, 'The Psalm of 4Q372 1 within the Context of Second Temple Prayer,' CBQ 54 (1992): 67-79. 
could be the collective Israel, of course; but it seems to me more likely that he is no other than the individual who speaks in the first person in line 2 of the fragment, who does something "in Israel" in line 3, and who considers himself a servant of God, to whom he appeals in line $6 .^{25}$

These two texts and the references to God's paternity in the Hodayot illustrate the first of the two tendencies: the use of the theme of sonship to express the inner relationship with God at a personal level. The second tendency, to restrict divine sonship to the members of the group (the same to whom the divine angelic sonship has been extended), is a logical and unavoidable consequence of the premises articulated by two basic documents: the Damascus Document appropriates "Israel" as a designation of the group, and the Rule of the Community transforms the concept of covenant into "the covenant of the community." In other texts of a more eschatological character, such as the War Scroll or the Rule of the Congregation, after the destruction of all "sons of darkness" the "new covenant" and "the covenant of the community" will be co-extensive with "Israel" and it will form "all the congregation of Israel." At this moment, of course, all the sons of Israel will be "sons of light," and consequently "sons of God."26

\section{(3) The King, "son of God"}

In the Hebrew Bible the king is the only individual who is called "son of God." This special relationship of the king with God has been explained in many ways: as a divinization of the king, influenced by the model of Egyptian religion, ${ }^{27}$ as due to the influence of the Assyro-Babylonian idea of the king as "image of God," 28 as a result of the "divine adoption" of the

25 4Q460 9 i 5-6. The text has been published by Erik Larson in Philip S. Alexander et al., Qumran Cave 4.XXVI: Miscellanea, Part 1 (DJD 36; Oxford: Clarendon, 2000), 382.

${ }^{26}$ For a detailed treatment of this point, see Florentino García Martínez, "Invented Memory: the 'Other' in the Dead Sea Scrolls," in Qumranica minora II: Thematic Studies on the Dead Sea Scrolls (STDJ 63; Leiden: Brill, 2007), 187-218.

27 By H. Donner, Adoption oder Legitimation: Erwägungen zur Adoption im Alten Testament auf dem Hintergrund der altorientalischen Rechte (Aufsätze zum Alten Testament aus vier Jahrzehnten; Berlin: Walter de Gruyter, 1994); Helmut Merklein, “Ägyptische Einflüsse auf die messianische Sohn-Gottes-Aussage des Neuen Testaments," GeschichteTradition-Reflexion. FS Martin Hengel (eds H. Cancik, H. Lichtenberger and P. Schäfer; 3 vols.; Tübingen: Mohr Siebeck, 1996) III: Frühes Christentum, 21-48, applies this ideas to the New Testament.

28 By J.-G. Heintz, "Royal Traits and Messianic Figures: A Thematic and Iconographic Approach," The Messiah. Developments in Earliest Judaism and Christianity (ed. J.H. Charlesworth; Minneapolis: Fortress Press, 1992), 52-66. 
king at the moment of his enthronement; ${ }^{29}$ or as a simple intensification of the divine sonship of Israel within the context of the covenant. ${ }^{30}$ Whatever the explanation, there is no doubt at all that this "divine sonship of the king" express a very peculiar relationship of the king with the divinity. ${ }^{31}$

The classic proof-texts with respect to this "divine sonship of the king" are those provided by the royal Psalms (Ps 2, Ps 110 [at least according to the interpretation of the LXX] and for some scholars Isa 9:1-6) on the one hand, ${ }^{32}$ and on the other the oracle of Nathan on the Davidic dynasty preserved in 2 Sam 7:14, repeated in 1 Chron 17:13-14 and 22:10-11, and clearly evoked in Ps 89:27-30, to which 1 Chron 28:9-10 alludes when David transmits the instructions for the building of the temple to Solomon, and 2 Chron 7:17-20 after the dedication of the temple. ${ }^{33}$

At Qumran we find some echoes of these biblical texts on the divine sonship of the king, but the motif of divine sonship itself has disappeared. In the Words of the Luminaries, for example, there is a clear allusion to Nathan's oracle without the language of sonship:

And you chose the land of Judah and established your covenant with David so that he would be like a shepherd, a prince over your people, and would sit in front of you on the throne of Israel forever. (4Q504 1-2 4:6-8) $)^{34}$

On the other hand, we find other texts, such as $4 \mathrm{Q} 174,35$ where the language of sonship of the biblical text has been preserved, but where the

29 By Roland de Vaux, "L'adoption divine, " in Les Institutions de l'Ancien Testament. I (Paris: Cerf, 1958), 171-173.

30 By Brendan Byrne, "Sons of God" - "Seed of Abraham," 17-18.

31 The topic has been studied from many different perspectives. See Trygve N.D. Mettinger, King and Messiah. The Civil and Sacral Legitimation of the Israelite Kings (Lund: Gleerup, 1976). The study of Gerald Cook, "The Israelite King as Son of God," ZAW 73 (1961): 202-225, in spite of its age, is still valuable.

32 For a classic statement on the royal ideology of Israel in its oriental context, see Sigmund Mowinckel, He That Cometh (trans. G. Anderson; Nashville: Abingdon Press, 1955), and his The Psalms in Israel's Worship, 2 vol. (Nashville: Abingdon Press, 1962).

33 The most complete study of the dynastic oracle and of its interpretation is Kenneth E. Pomykala, The Davidic Dynasty Tradition in Early Judaism (SBL Early Judaism and Its Literature 7; Atlanta: Scholars Press, 1998).

34 Edited by Maurice Baillet, Qumrân Grotte 4. III (DJD 7; Oxford: Clarendon, 1982), 143-144; translation by Florentino García Martínez, The Dead Sea Scrolls Translated, 415.

35 Published by James M. Allegro, Qumrân Cave 4.I (DJD 5; Oxford: Clarendon, 1968), 53-57. See the study by George Brooke, Exegesis at Qumran. 4QFlorilegium in its Jewish Context (JSOTSup 29; Sheffield: Sheffield Academic Press, 1985). The text is now considered to be part of a larger composition, part of which is also 4Q177; see Annette Steudel, Der Midrash zuer Eschatologie aus der Qumrangemeinde (4QMidrEschat ${ }^{a . b}$ ) (STDJ 13; Leiden: Brill, 1994). 
biblical text is applied not to an existent king but to the king expected at the end of times:

And "YHWH declares to you that he will build you a house. I will raise up your seed after you and establish the throne of his kingdom for ever. I will be a father to him and he will be a son to me." This (refers to the) "branch of David" who will arise with the Interpreter of the law who will rise up in Zion in the last days. (4Q174 1-3 1:10-12) ${ }^{36}$

These texts prove that the mythological language of the royal Psalms and the dynastic oracle of Nathan have provided the textual basis for the development of the messianic idea also at Qumran, and have contributed definitely to the formulation of the expectation "at the end of times" of a royal Messiah, "son of God."

The last category of texts to deal with refers, in my opinion, to the same figure, also using the language of sonship, thereby allowing us to suggest that the title "son of god" could also be used as a messianic title at Qumran.

\section{(4) The Messiah, "son of God"}

The first of the texts which applies the language of divine sonship to the expected "anointed" is a disputed text in the Rule of the Congregation (1QSa 2:11-14):37 "This is the assembly of the famous men, [those summoned to] the gathering of the community when [God] begets the Messiah with them." According to this reading and reconstruction of the text, the language of sonship is applied directly to the expected Messiah, who is "begotten" or "fathered" by God within the community. The key word, "וליד, is of uncertain reading and is very much disputed. ${ }^{38}$ In my opinion,

36 The Dead Sea Scrolls Translated, 136.

37 The text was edited by D. Barthélemy in D. Barthélemy - Józef T. Milik, Qumran Cave 1 (DJD 1; Oxford: Clarendon, 1955), 108-118. Translation in The Dead Sea Scrolls Translated, 127.

38 The reading יולידis the one of the first editor, Barthélemy, and the excellent photographs in my possession confirm it. But Barthélemy, following a suggestion of Milik, understands the word as a copyist's error for 'ריולי, which would give to the whole sentence the meaning "au cas où Dieu mènerait le Messie avec eux" (DJD 1, 117). Yigael Yadin, "A Crucial Passage of the Dead Sea Scrolls," JBL 78 (1959): 238-241, reads יועדו', and J. Licht, The Rule Scroll. A Scroll from the Wilderness of Judaea (Jerusalem: Bialik, 1965) (Hebrew), 27, lists eight different readings and prefers יתודו "will unite," which is the reading followed by Lawrence Schiffman, The Eschatological Community of the Dead Sea Scrolls. A Study of the Rule of the Congregation (SBLMS 38; Atlanta: Scholars Press, 1989), 53-54. Emile Puech, "Préséance sacerdotale et Messie-Roi dans la Règle de la Congrégation (1QSa ii 11-12)," RevQ 63 (1996) : 351-365, proposes to read יתגלה and interprets the sentence "quand sera révélé le Prince Messie parmi eux." Hartmut Stegemann, "Some Remarks to 1QSa, to 1QSa 
however, it represents the best reading and in view of the use of ילדתיך in Ps 2 , it is quite normal.

The next text (4Q369) is unproblematic in terms of uncertain readings, but its fragmentary character leaves us uncertain as to whom the language of sonship (indicated by the use of בן בכור "first born," the phrase "and you made him for you a first-born son," and the expression כאב לבנר "like a father to his son") is being applied. ${ }^{39}$

Two different interpretations of the protagonist's identity have been proposed. The first sees him as an individual figure that will arise to guide and rule the Israel of the end of times. ${ }^{40}$ The second sees this figure as a collective expression for Israel. ${ }^{41}$ The strongest argument with respect to this collective interpretation is the use of בני בכרי Exod 4:22, and the application in ancient Jewish literature of some of the motifs that appear in our text to Israel. The strongest argument with respect to the individual and messianic interpretation is the influence of Ps 89:27-28, where we find three of the elements appearing in the text applied to the king: God will make him "first-born" (בכור), he will establish him as the most exalted king on earth, and the king will call God "father." If we add to these elements from Ps 89 a possible parallel with another fragmentary Qumran text where the same expression בכרי also appears, I think that the balance ultimately inclines us towards the individual and messianic interpretation.

and to Qumran Messianism," RevQ 65-68 (1996) : 478-505, suggests to read יואכלו," When they eat together, and the messiah is together with them." All these readings seem to me very difficult palaeographically, and clearly inferior to the original reading of the first editor.

39 4Q369 1 ii 4-10. The text has been edited by Harold Attridge and John Strugnell, in Harold Attridge et al., Qumran Cave 4.VIII: Parabiblical Texts Part 1 (DJD 13; Oxford: Clarendon, 1994), 356-357.

40 The editors remark: "The prayer or prophecy mentions a place, most likely Jerusalem, and a 'prince' or 'ruler' (cf. line 7) whose identity remains obscure. If there is only one figure involved, he is to 'establish God's name' in a special place (line 1); have descendants who will have an eternal possession (line 4); be purified by God's judgments (line 5); enjoy the status of God's son (line 6), as well as heavenly glory (line 8). Such an individual may be either a biblical figure such as Abraham or David, or, more likely, an eschatological messianic figure." (DJD 13, 358). The messianic interpretation has been defended strongly by Craig A. Evans, "A Note on the 'First-Born Son' of 4Q369," DSD 2 (1995): 185-201 and in "Are the 'Son' Texts at Qumran Messianic? Reflections on 4Q369 and Related Scrolls," in Qumran-Messianism (eds James H. Charlesworth et al.; Tübingen: Mohr Siebeck, 1998), 135-153. Also by Marc Philonenko, “De la 'Prière de Jésu' au 'Notre Père' (Abba, targum du Psaume 89,27; 4Q369 1,21-12; Luc 11,2," RHPR 77 (1997): 133-140, and Geza Xeravits, King, Priest, Prophet. Positive Eschatological Protagonist in the Qumran Library (STDJ 47; Leiden: Brill, 2003), 89-94.

41 Strongly defended by James L. Kugel, “4Q369 'Prayer of Enosh' and Ancient Biblical Interpretation," DSD 5 (1998): 119-148. 
4Q458, published as 4 QNarrative $A^{42}$ the expression appears without any context. In the best preserved fragments (4Q458 1), however, we find another expression, "the beloved" (לידיד in line 1, and הידיד in line 2), which could refer to the same personage, as well as the expression "anointed with the oil of kingship" משיח בשמן מלכות (4Q458 2 ii 6) which clearly refers to the royal Messiah, because, as the editor notes, "the establishment of his kingdom is apparently connected with both the destruction of the uncircumcised referred to in line 4 and the establishment of righteousness among the chosen people of God." 43 In spite of the uncertainties brought about by poor preservation, therefore, these texts also show that the language of sonship was applied to the royal Messiah as an extension of the sonship language originally applied to the king.

Also 4Q246, the famous "son of God" text, now published under the official title $4 Q$ Apocryphe de Daniel ar, applies the language of sonship to the Messiah:

He will be called son of God, and they will call him son of the Most High. .. His kingdom will be an eternal kingdom, and all his paths in truth and uprightness. The earth (will be) in truth and all will make peace. (4Q246 ii 1-6) ${ }^{44}$

Although the word "anointed" does not appear in this Aramaic text, the messianic interpretation of its exalted protagonist is now generally accepted. ${ }^{45}$ Together with the other texts quoted, 4Q246 offers us the proof not only that the sonship terminology of the king as "son of God" was transferred to the future Messiah at Qumran, but that the title "son of God" could be applied to the Messiah without the need to specify its character as "anointed."

42 4Q458 has been published by Erik Larson in Philip S. Alexander et al., Qumran Cave 4. XXVI: Miscellanea, Part 1 (DJD 36; Oxford: Clarendon, 2000), 353-365.

43 Ibid., 360.

44 Published by Emile Puech in George Brooke et al., Qumran Cave 4. XVII: Parabiblical Texts, Part 3 (DJD 22; Oxford: Clarendon, 1996), 165-184.

45 See the presentation of part of the very abundant bibliography originated by the text (before and after the official publication) in Johannes Zimmermann, "Observations on 4Q246 - The 'Son of God,'" in Qumran Messianism (eds James H. Charlesworth et al.; Tübingen: Mohr Siebeck, 1998), 175-190. In the same volume John J. Collins strongly defends the messianic character of the text in the section "Messiah and Son of God" (107112) of his contribution, "Jesus, Messianism and the Dead Sea Scrolls," 100-119. Even the editor of the fragment, who in the official edition left open the possibility of a negative interpretation of the protagonist, accepts now its messianic character: Emile Puech, "Le 'Fils de Dieu' en 4Q246," Eretz Israel 26 (1999): 143-152 (FS F.M. Cross). "Ceux-ci conviennet mieux, il faut le reconnaître, au roi messie, ainsi que la séquence en rapport avec la victoire eschatologique du roi à la tête de son peuple, car il n'y a pas de royaume sans roi" (149). 
The analysis of the Qumran texts on divine sonship shows that it is applied to selected individuals, that it is extended to the individual members of the community, that it is not used of historical kings but applied to the expected eschatological king, and that it has become one of the characteristics of the expected King Messiah. What about Philo? We now turn to him to look for elements which develop or add some new aspects to the idea of sonship in the Hebrew Bible.

\section{Divine Sonship in Philo}

As a result of the influx of Greek philosophical ideas and Roman juridical praxis, sonship in Philo is a much more complex phenomenon than in the Hebrew Bible. ${ }^{46}$ Perhaps the most complete typology of sonship is the one given in Mut. 147, when Philo comments on Gen 17:16, the promise of God to give Abraham a son (TÉkvov):

So much for His saying that He will give one, but the word actually used in this passage, "bairn," (TÉkvov) is used not without care or consideration. He wishes

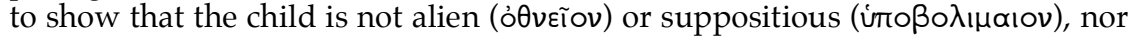

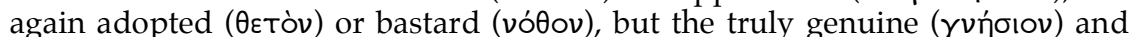

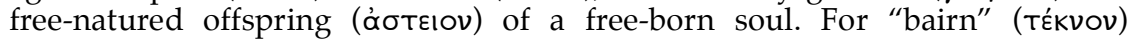
derived from "bearing" (Tókov) is used to bring out the affinity which is the natural tie between parents and children. (Mut. 147) ${ }^{47}$

No less than six adjectives are referred here to the word "child" ("bairn" in the PLCL translation), covering the whole gradation from

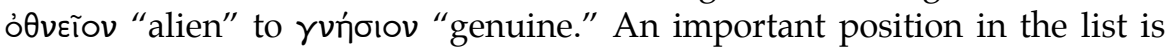
taken by $\theta \varepsilon$ cós, the "adopted," which represent a category unknown in the Hebrew Bible, but that Philo will use to attribute divine sonship to select individuals. ${ }^{48}$ The best known case is Abraham. ${ }^{49}$ In a famous passage in Sobr. 56, Philo writes, using different terminology:

\footnotetext{
46 For an excellent overview of sonship in Philo, see Cristina Termini, "Tipologías de filiación en Filón de Alejandría," in Filiación: Cultura pagana, religión de Israel, orígenes del Cristianismo (eds J.J. Ayán Calvo et al.; Estructuras y procesos: Serie Religión; Madrid: Trotta, 2005), 131-167.

47 Translations are taken from PLCL, here vol. V, 217-19.

48 For a detailed analysis of the terminology of adoption, see James M. Scott, Adoption as Sons of God. An Exegetical Investigation into the Background of YIOOE $I$ IA in the Pauline Corpus (WUNT 2.Reihe 48; Tübingen, Mohr Siebeck, 1992), 13-57; see 39-45 for the word

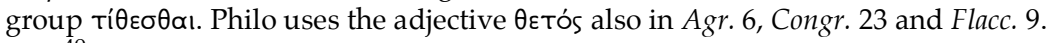

49 See Samuel Sandmel, Philo's Place in Judaism. A Study of the Conceptions of Abraham in Jewish Literature (Augmented Edition; New York: Ktav, 1971).
} 
And therefore He says plainly of Abraham, "shall I hide anything from Abraham My friend?" (Gen 18:17). But he who has this portion has passed beyond the bounds of human happiness. He alone is nobly born, for he has registered

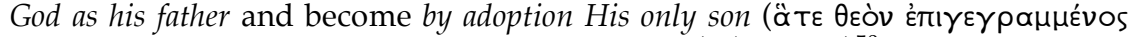

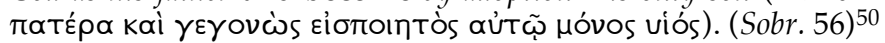

The topic of divine adoption in Philo in general, and the example of Abraham in particular, has been amply studied and needs no further comment. ${ }^{51}$ I will simply underline the parallel with the "angelification" of selected individuals we have found in the Dead Sea Scrolls. Philo uses here the Graeco-Roman category of adoption to achieve the same results that the Scrolls have reached by applying angelic language to select individuals (and to the members of the community).

Together with divine adoption, the two most innovative elements (in my opinion) in the theme of divine sonship in Philo are the consideration of

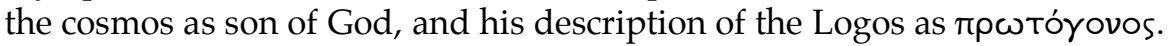
I will briefly comment on both.

\section{The Cosmos as Son of God}

Philo is well aware of the potentiality of the metaphor of sonship. In Deus 31 he applies it both to the sensible world and to the intelligible world, the

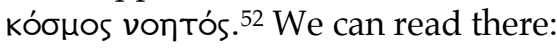

For this universe, since we perceive it by our senses, is the younger Son of God

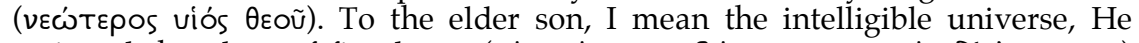

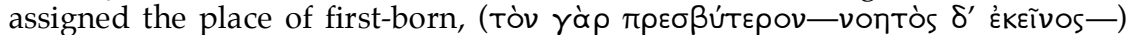
and purposed that it should remain in His own keeping. (Deus 31$)^{53}$

The distinction between the two worlds is clear and it serves to underline not a chronological priority (time belongs only to the sensible word), but the fact that the intelligible world derives directly from the first cause and remains in God. ${ }^{54}$ But this priority of the intelligible world does not imply that the sensible world is without value. In another text, Philo quotes Prov 8:22 to associate wisdom with the generation of the sensible world, which he calls "beloved," ararntós:

50 PLCL III, 473.

51 See the treatment by Scott, Adoption, 88-96 and Termini, " Tipologías," 135-40.

52 On the Philonic expression, see the comments of David T. Runia, On the Creation of the Cosmos according to Moses (Philo of Alexandria Commentary Series 1; Leiden: Brill, 2001), 136.

53 PLCL III, 25-27.

54 See the excursus of Runia, On the Creation of the Cosmos, 151-152, and in more detail his Philo of Alexandria and the Timaeus of Plato (Philosophia Antiqua 44; Leiden: Brill, 1986). 


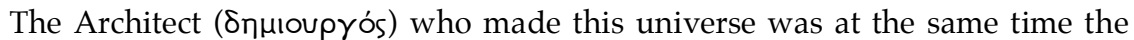
father of what was thus born, whilst its mother was the knowledge possessed by its Maker. With His knowledge God had union, not as men have it, and begat created being. And knowledge, having received the divine seed, when her travail was consummated bore the only beloved son who is apprehended by the senses, the world which we see. $(\text { Ebr. 30-31) })^{55}$

Here Philo mixes the usual metaphor of the Hebrew Bible (God as Maker of the World) with the metaphor of fatherhood and the language of sonship, which in the Bible is never applied to the creation of the world. In the same way that the Graeco-Roman idea of adoptive sonship has allowed him to qualify Abraham as son of God, Greek philosophical ideas have provided the basis for the application of the idea of sonship to the world. This is not a general assumption, but in this case can be proved directly with a quote. In the brief summary of the Timaeus of Plato that Philo has included in Aet. 15 we can read:

But this subtlety of theirs is not so good or true an idea as the view before mentioned, not merely because throughout the whole treatise he speaks of the great Framer of deities (тòv $\theta \varepsilon \circ \pi \lambda \alpha^{\prime} \sigma \tau \eta \nu$ ) as the Father and Maker and Artificer

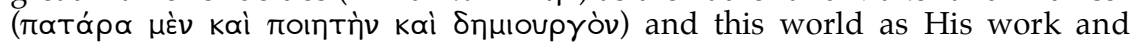

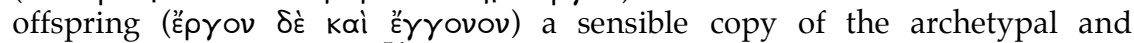
intelligent model. (Aet. 15) 56

We can only guess the reasons why Philo (who, as Runia indicates, clearly prefers the Biblical metaphor of the "maker," rointris, which underlines the difference between creator and creature and the relationship between the sensible world as a copy of the intelligible world $)^{57}$ introduces also the metaphor of the cosmos as son of God. But the more dynamic metaphor of a father-son relationship certainly allows him to introduce the possibility of a return to God. As he says in Spec. I, 41:

This universe has been my teacher, to bring me to the knowledge that Thou art and dost subsist. As Thy son, it has told me of its Father, as Thy work of its

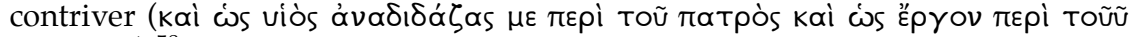
TEXVítou). ${ }^{58}$

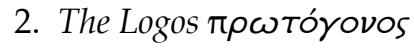

The last element of Philo's use of the language of sonship I wanted to

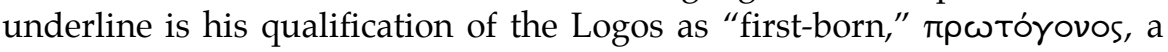

\footnotetext{
55 PLCL III, 333-35.

56 PLCL IX, 195.

57 Runia, Philo of Alexandria and the Timaeus of Plato, 424.

58 PLCL VII, 123.
} 
qualification that is closely related to his definition of the intelligible world as "older son" because the intelligible world is in the Logos and somehow is identical with the Logos, though without exhausting it. "In the same way the cosmos composed of the ideas would have no other place than the divine Logos who gives these (ideas) their ordered disposition," it is said in Opif. 20 in Runia's translation. ${ }^{59}$

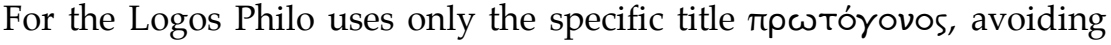

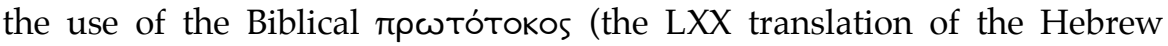
בכור), which he reserves for the firstborn of men and animals. Philo gives this title to the Logos when describing some of its more important functions. ${ }^{60}$ In Agr. 51, quoting Psalm 23, he says:

This hallowed flock He leads in accordance with right and law, setting over it

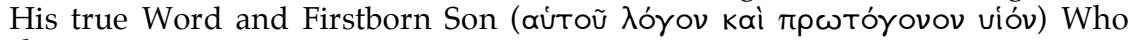
shall take upon Him its government like some viceroy of a great King; for it is said in certain place: "Behold I AM, I send My Angel before thy face to guard thee in the way" (Exod 23:20) (Agr. 51). ${ }^{61}$

The function here attributed to the Logos, the first-born son, is that of guidance of the cosmos as ürapxos of God, who is the Shepherd of the whole universe. The use of Exod 23:20 as a proof text for this idea is interesting, because the function of the Angel/Logos is no longer to guide and protect the people of Israel through the desert, but to conduct katà Síknv kaì vómov the whole cosmos as God's lieutenant.

In Conf. 62-63, one of the few texts in which the Logos is presented as acting as Demiurge, Philo comments on Zech 4:12, and playing with the

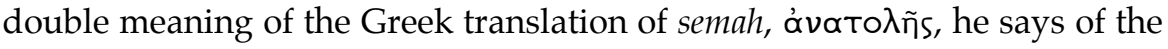
Logos:

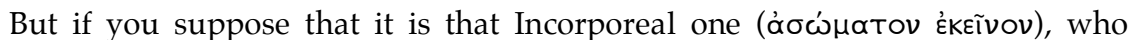
differs not a whit from the divine image, you will argue that the name of

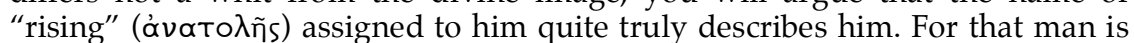

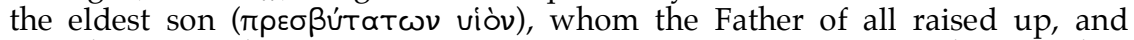

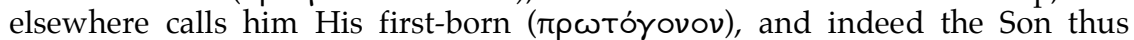
begotten followed the ways of his Father, and shaped the different kinds, looking to the archetypal patterns which the Father supplied. (Conf. 62-63) ${ }^{62}$

59 Runia, On the Creation of the Cosmos, 51, and see his comments, 142-43.

60 It is used in Post. 63, Agr. 51, Conf. 63, 146, Fug. 208, Somn. 1:215. See Peder Borgen, et al., The Philo Index: A Complete Greek Word Index to the Writings of Philo of Alexandria (Eerdmans - Brill: Grand Rapids - Leiden, 2000), 303.

61 PLCL III, 135,

62 PLCL IV, 45. 
The Logos is "begotten" ( $\gamma \varepsilon \nu \nu \eta \theta \varepsilon ı)$ by God and acts imitating

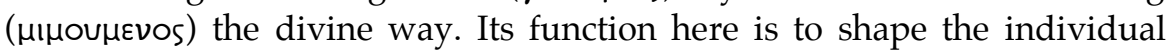
species following divine models.

Finally, Philo uses the same title of $\pi \rho \omega$ tóyovov when describing the priestly functions of the Logos, as High Priest who brings the cosmos to God. We can read in Somn. I, 215:

For there are, as it is evident, two temples of God: one of them this universe, in

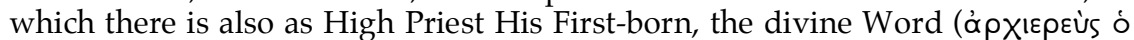

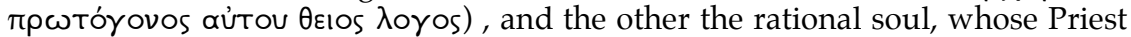

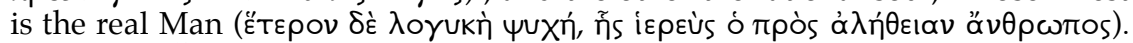
(Somn. 215) ${ }^{63}$

And, of course, in the beautiful passage Conf. 145-147, where the many

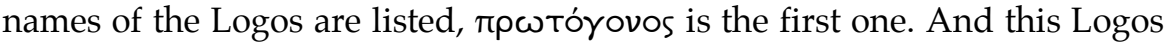
will play an essential role as mediator in the intellectual, moral and religious transformation of men, which makes them sons of God. But the analysis of this beautiful passage must to be left for others who are more competent.

KULeuven - RUGroningen 